INDEPENDENT JOURNAL OF MANAGEMENT \& PRODUCTION (IJM\&P)

http://www.ijmp.jor.br

v. 9, n. 2, April - June 2018

ISSN: 2236-269X

DOI: 10.14807/ijmp.v9i2.688

\title{
CUSTOMER REQUIREMENTS FOR THE CONTINUOUS IMPROVEMENT OF PRODUCT-SERVICE SYSTEM: A CONCEPTUAL APPROACH
}

\author{
Cristiane Alves Anacleto \\ Instituto Federal de Minas Gerais, Ribeirão das Neves, Brazil \\ Email: cristianeanacleto@yahoo.com.br
}

Edson Pacheco Paladini Universidade Federal de Santa Catarina, Brazil Email: paladini@floripa.com.br

Caroline Rodrigues Vaz Universidade Federal de Santa Catarina, Brazil Email: karollrvaz@gmail.com

Submission: $28 / 06 / 2017$

Revision: $13 / 07 / 2017$

Accept: 27/07/2017

\section{ABSTRACT}

Identifying customer requirements is a strategic element for consolidating product-service systems (PSSs) in the market. However, literature on empirical studies has devoted relatively little attention to this topic. The purpose of the present work is to identify PSS customer requirements by analyzing empirical studies. Toward this goal, we present here a structured systematic literature review. This study systematically reviews 269 articles published until 2015 in the PSS field. About $10 \%$ of the publications reviewed describe empirical studies that identify PSS-customer requirements. After analyzing the content of these articles, we identify 37 requirements clustered around three criteria: (i) type of PSS, (ii) type of business transaction, and (iii) customer requirements that relate to product, service, or general aspects of PSS. The empirical studies investigated in this literature review focused on the business-tobusiness context. This study support PSS provider meet customer requirements. Then, they will be more successful in offering the PSS.

[http://creativecommons.org/licenses/by/3.0/us/]

Licensed under a Creative Commons Attribution 3.0 United States License 
INDEPENDENT JOURNAL OF MANAGEMENT \& PRODUCTION (IJM\&P)

http://www.ijmp.jor.br

v. 9, n. 2, April - June 2018

ISSN: 2236-269X

DOI: 10.14807/ijmp.v9i2.688

Keywords: product-service system; customer requirements; systematic literature review

\section{INTRODUCTION}

About two decades ago, the sale of individual products predominated in traditional business models, but this model is out of phase with the new landscape of consumption, which calls for integrated solutions that benefit the customer, consequently differentiating the provider and making them more competitive. In addition, global competition has intensified the dynamics of the business environment (PAN; NGUYEN, 2015). In this context, different strategies have been created in the marketplace, such as product-service systems (PSSs).

A PSS aims to strengthen the strategic competitiveness of manufactured goods and enable sustainability and customer satisfaction by combining products with services (LEE; GEUM; LEE; PARK, 2015; REIM; PAIRDA; ÖRTQVIST, 2015). A PSS refers to tangible goods and services that are combined to meet the needs of customers (YOO; KIM; RHEE, 2012).

The PSS definitions that appear in the literature highlight three pillars: (i) sustainability, (ii) competitiveness, and (iii) meeting new customer needs. The needs are related to different requirements and to how the supplier meets these needs. Thus, understanding customer needs and satisfaction appears to be fundamental to the success of PSSs, making it a strategic element for PSS providers (RAJA; BOURNE; GOFFIN; ÇAKKOL; MARTINEZ, 2013; GENG; CHU, 2012).

Customer requirements should be identified at the early stages of PSS development and should act as input to stimulate continuous improvement in PSSs (CASSIA; UGOLINI; COBELLI; GILL, 2015; KIM; SON; YOON; PARK, 2015). Although PSSs provide multiple benefits for customers, these benefits are not sufficiently explained to generate market acceptance.

Empirical studies that focus on customer-identification needs are scarce (KIM et al., 2015; CHOU; CHEN; CONLEY, 2015; SAKAO; LINDAHL, 2015). Thus, new research is required to identify PSS customer requirements in the context of business-to-business (B2B) and business-to-consumer (B2C) models (REXFELT; HIORT AF ORNÄS, 2009; SCHENKL; RÖSCH; MÖRTL, 2014). 
INDEPENDENT JOURNAL OF MANAGEMENT \& PRODUCTION (IJM\&P)

http://www.ijmp.jor.br

v. 9, n. 2, April - June 2018

ISSN: 2236-269X

DOI: 10.14807/ijmp.v9i2.688

The literature tends to focus on how to develop PSSs, sustainability, and successful applications. Most works focus on the PSS provider (VEZZOLI; CESCHIN; DIEHL; KOHTALA, 2015; MAZO; BORSATO, 2014; GENG; CHU; XUE; ZHANG, 2011). Zheng, Ming, L and He (2015) explain that one of the biggest challenges to overcome for a successful PSS is to gain market acceptance, which is closely related to the customer-satisfaction requirements.

Given this context, the present work aims to improve the understanding of PSS customer requirements. Thus, the main objective of this work is to identify customer requirements in the literature on empirical studies of PSSs.

This report continues in four sections. Section 2 presents the theoretical framework of PSSs and customer requirements. Section 3 describes the research techniques and the methods adopted herein, and the Section 4 presents and discusses the results. Finally, Section 5 concludes and provides recommendations for future work.

\section{THEORETICAL BACKGROUND}

According to Mazo and Borsato (2014), the PSS concept was created in Europe in 1990. Goedkoop, Van Halen, Te Riele and Rommens published the first PSS study in 1999. New terms have since appeared, such as servitization, integrated product service, transition from product to service, etc. The PSS concept has been evolving since the 1990s. However, the predominant contributions have involved areas of environmental and social sciences (GOEDKOOP; VAN HALEN; TE RIELE; ROMMENS, 1999; MONT, 2001). Chou et al. (2015) and Vezzoli et al. (2015) state that academic interest in PSSs goes beyond the theme of environmental sustainability and includes social and economic issues.

Cook (2004) conceptualizes three types of PSS: The product-oriented PSS consists of offering a tangible good with additional services. In this case, the customer owns the tangible good. Services are offered by the PSS provider and add value to the tangible good, for example, a maintenance contract after purchase. The use-oriented PSS consists of selling the use of a tangible product along with services that add value to the product, for example, leasing industrial equipment. In this case, the tangible good is owned by the PSS provider. The result-oriented PSS offers an outcome or competence to the customer, and the product remains with the provider. 
INDEPENDENT JOURNAL OF MANAGEMENT \& PRODUCTION (IJM\&P)

http://www.ijmp.jor.br

v. 9, n. 2, April - June 2018

ISSN: 2236-269X

DOI: 10.14807/ijmp.v9i2.688

An example of result-oriented PSS is the outsourcing of cleaning services offered by some companies.

To better understand the PSS, it is important know its customer requirements.

Identifying customer requirements helps PSS providers add more value to their offer (TOOSSI; LOCKETT; RAJA; MARTINEZ, 2013). Assessing PSS feasibility from the customer viewpoint increases the chances of success and reduces the risk of failure. Understanding customer requirements plays an important role in spreading the use of PSSs (SHIH; CHOU, 2011; SAKAO; LINDAHL, 2012).

Customer requirements contribute to the customer perception of value (RAJA et al., 2013; TOOSSI et al., 2013). Therefore, they influence the acceptance of PSS (REXFELT; HIORT AF ORNÄS, 2009). The requirements should be considered to estimate the customer satisfaction that relates to individual market needs (TU; HUANG; HSU; CHENG, 2013). Therefore, customer satisfaction varies according to the target market for the provision of PSS. Rexfelt and Hiort Af Ornäs (2009) argue that PSS performance in terms of compliance with customer requirements can be divided into several dimensions of satisfactions related to tangible goods and services.

These requirements may be tangible or intangible (TOOSSI et al., 2013) and they relate to the PSS components (i.e., the tangible goods or services) (GENG; CHU; XUE; ZHANG, 2010). However, Geng et al. (2010) state that tangible-good requirements are often specific and related to the type of industry in which the PSS evolves. The tangible asset requirements and services are interdependent. Kim and Yoon (2012) state that customer requirements can generate contradictions in a PSS project because of the interdependence between tangible goods and services. Therefore, to facilitate the development of PSSs, customer requirements are classified into two groups: one related to tangible goods and the other related to services (SHENG; LU; WU, 2015).

Not all customer requirements are feasible, which prevents them from all being included in each PSS project. Therefore, Geng et al. (2011) suggest that a weight based on customer importance be associated with each customer requirement. Geng and Chu (2012) explain that classifying the requirements based on the importance to the customer is crucial to meet customer needs. However, Kuo 
DOI: 10.14807/ijmp.v9i2.688

(2013) suggests that customer requirements should be identified by evaluating the consumption of the separate components of the PSS or of the integrated solution of both.

\section{RESEARCH METHODOLOGY}

According to the ratings by Creswell (1994) and Plewis and Mason (2005), this study uses a qualitative approach because it analyzes the content of the articles identified. According to the ratings of Minor, Hensley and Wood (1994) and Dangayach and Deshmukh (2001), this study may be classified as conceptual because it is based on secondary data from published studies and its goal is to generate knowledge about PSS-customer requirements.

This study uses a systematic literature review (SLR), like Lipkin (2016). Mian, Conte, Natali, Biolchini and Travassos (2005) state that a SLR is a research approach with well-defined steps and that is planned according to a protocol and to previously established objectives. Tranfield, Denyer and Smart (2003) suggest three stages for a SLR: (i) planning the research, (ii) implementing the SLR, and (iii) conclusions.

\subsection{Planning research}

A research protocol was first constructed based on the following information: search database, keywords, language, types of study, time horizon, criteria for inclusion of articles in the sample, procedures for search and selection of studies, and content analysis. The databases selected for the search were Scopus and ISI Web of Knowledge (Web of Science), the latter of which is the most used in research on PSSs. These bases allow metadata to be exported for analyzing publications, citations, and references.

The following keywords were used for the search: product-service system, product service offerings, servitization, transition from products to service, integrated product-service, and productization. These keywords were defined based on the criteria indicated by Eloranta and Turunen (2015): articles that used SLRs in studies about PSSs. Therefore, the following authors stand out: Reim et al. (2015), Oliva and Kallenberg (2003).

For a better selection of items in the database, the following three filters were used: (i) type of document, (ii) language, and (iii) time horizon. Also included were 
the sample articles written in English and published by 2015. According to Eloranta and Turunen (2015) and Seuring and Müller (2008), articles published in journals undergo a careful process of peer review prior to publication. After using filters, articles were selected that contained the given search term in at least one of the fields: title, abstract, or keywords. This constituted the first selection of articles.

A second selection was made from this first set of articles. We included studies that conducted empirical research with PSS customers, where empirical studies are those whose data are collected directly by the researchers from the units of analysis, in this case, PSS customers.

Metadata (author, title, abstract, keywords, and references) were exported to the bibliography-management software EndNote X5 for analysis and storing. The use of this software facilitates the manipulation of metadata items. Finally, the data extracted from the articles were manipulated by using a Microsoft Excel spreadsheet.

\subsection{Implementation of systematic literature review}

The SLR was implemented in March 2016 by filtering the Scopus and Web of Science databases based on the article-inclusion criteria. The first phase of the search formed two sets of articles for each keyword, as shown in Table 1.

Table 1: Phases developed for the construction of final-article sample.

\begin{tabular}{llll}
\hline Keywords & \multicolumn{2}{l}{ Database } & Sample \\
\hline Phase 1 & Scopus & $\begin{array}{l}\text { Web } \\
\text { of Science }\end{array}$ \\
\hline Product-service system & 364 & 159 & 523 \\
Product service offering & 35 & 8 & 43 \\
Servitization & 117 & 82 & 199 \\
Transition from products to service & 5 & 1 & 6 \\
Integrated product-service & 23 & 16 & 39 \\
Productization & 47 & 13 & 60 \\
\hline Quantity of articles & 591 & 279 & $\mathbf{8 7 0}$ \\
\hline Phase 2 & $\mathbf{3 3 2}$ & $\mathbf{1 5 8}$ & \\
\hline Phase 3 & Partial number of articles & $\mathbf{2 6 9}$ \\
\hline Phase 4 & Partial number of articles & $\mathbf{3 1}$ \\
\hline Phase 5 & Total number of articles & $\mathbf{2 3}$ \\
\hline
\end{tabular}

Source: Elaborated by the author authors 
INDEPENDENT JOURNAL OF MANAGEMENT \& PRODUCTION (IJM\&P)

http://www.ijmp.jor.br

v. 9, n. 2, April - June 2018

ISSN: 2236-269X

DOI: 10.14807/ijmp.v9i2.688

The second step was the elimination of duplicate articles from the sample from each database, which removed 332 articles from the Scopus database sample and 158 from the Web of Science sample. In the third phase, articles were eliminated whose full text was not available for access via the digital library of the Federal University of Santa Catarina, following which the systematic search in the databases resulted in a partial sample of 269 articles.

The partial sample was evaluated based on the findings and conclusions reported in the articles, which led to the formation of a new set of articles. This assessment was based on the three criteria cited above and led to a new partial sample of 31 articles. A complete reading of these 31 articles led to the elimination of 8 articles because it was unclear whether the work involved empirical research with PSS customers. Therefore, 23 articles were selected after implementing SLR.

The set of reference articles were used as a secondary source of analysis of the literature. After analyzing the results, we found that the studies retained involved empirical research with PSS customers. The studies retained: An et al. (2008), Kimita et al. (2009), Rexfelt and Hiort af Ornäs (2009), Geng et al. (2010), Geng et al. (2011), Shih and Chou (2011), Catulli (2012), Geng and Chu (2012), Geng et al. (2012), Kim and Yoon (2012), Carreira et al. (2013), Kuo (2013), Sakao and Lindahl (2012), Raja et al. (2013), Shimomura et al. (2013), Toossi et al. (2013), Tu et al. (2013), Kang, Lee and Lee (2014), Mazo and Borsato (2014), Mert, Waltemode and Aurich (2014), Kim et al. (2015), Lee et al. (2015), Sheng et al. (2015).

\section{CONCLUSIONS OF SYSTEMATIC LITERATURE REVIEW}

The findings presented herein are substantiated by the qualitative results of the content analysis. For this, two specialists validated the sample. Their feedback concerning the alignment of articles with the theme was positive. Thus, we proceeded to the analysis of the content of the articles to identify the customer requirements. According to Harwood and Garry (2003), content analysis identifies the information contained in items that fall under the proposed objective of the SLR. This allowed us to reduce the phenomenon investigated into defined categories, to interpret the data, and to identify trends in a discipline. 


\subsection{Requirements of product-service-system customers as defined in published literature}

This section addresses the requirements identified in the 23 articles of the sample. The 37 identified requirements are grouped based on the following three criteria:

i) PSS type. The requirements were grouped according to which type of PSS (COOK, 2004) they refer to.

ii) Type of transaction. The identified requirements refer to the $\mathrm{B} 2 \mathrm{C}$ or $\mathrm{B} 2 \mathrm{~B}$ contexts.

iii) PSS dimension. The customer requirements relate to product, service, or general aspects of PSS.

The requirements related to tangible goods have been named according to Garvin's dimensions of product quality (GARVIN, 1984): performance, features, reliability, conformance, durability, serviceability, aesthetics, maintainability, and perceived quality. Because some customers emphasize the importance of environmental and sustainability aspects associated with tangible goods, a new dimension was included called sustainability and environmental impact. Service requirements have been named according to the dimensions of quality service defined by Parasuraman, Zeithaml, Berry (1991): reliability, responsiveness, security, empathy, and tangible.

The choice of the studies of Garvin (1984) and Parasuraman et al. (1991) is supported by the empirical validation of their results by other studies. The general PSS dimension refers to aspects not directly related to tangible goods and services, for example, the contract between the customer and the PSS provider. The following sections include a description of customer requirements.

\subsection{Requirements associated with tangible-goods dimension}

The customer requirements related to tangible goods are shown in Table 2. Performance refers to whether the goods fulfill their main function related to their technical and functional characteristics. Product-oriented-PSS customers highlight PSS operating efficiency as a measure of performance. 
INDEPENDENT JOURNAL OF MANAGEMENT \& PRODUCTION (IJM\&P)

http://www.ijmp.jor.br

v. 9, n. 2, April - June 2018

ISSN: 2236-269X

DOI: 10.14807/ijmp.v9i2.688

Table 2: Customer requirements related to tangible goods.

\begin{tabular}{|c|c|c|c|c|}
\hline Requirement & $\begin{array}{l}\text { Product- } \\
\text { oriented } \\
\text { product- } \\
\text { service } \\
\text { system }\end{array}$ & \begin{tabular}{|l|} 
Use- \\
oriented \\
product- \\
service \\
system
\end{tabular} & \begin{tabular}{|l|} 
Result- \\
oriented \\
product- \\
service \\
system
\end{tabular} & $\begin{array}{l}\text { Type of } \\
\text { transaction }\end{array}$ \\
\hline Performance & $x$ & $x$ & $x$ & $\mathrm{~B} 2 \mathrm{~B}$ and $\mathrm{B} 2 \mathrm{C}$ \\
\hline Features & $\mathrm{x}$ & & $\mathrm{x}$ & $\mathrm{B} 2 \mathrm{~B}$ and $\mathrm{B} 2 \mathrm{C}$ \\
\hline Reliability & $\mathrm{x}$ & $\mathrm{x}$ & $\mathrm{x}$ & $\mathrm{B} 2 \mathrm{~B}$ and $\mathrm{B} 2 \mathrm{C}$ \\
\hline Availability & $x$ & $x$ & & B2B \\
\hline Maintainability & $\mathrm{x}$ & $\mathrm{x}$ & $\mathrm{x}$ & B2B \\
\hline Durability & & $x$ & $x$ & $\mathrm{~B} 2 \mathrm{~B}$ and $\mathrm{B} 2 \mathrm{C}$ \\
\hline Compliance & $\mathrm{x}$ & $x$ & $\mathrm{x}$ & $\mathrm{B} 2 \mathrm{~B}$ and B2C \\
\hline $\begin{array}{ll}\begin{array}{l}\text { Sustainability } \\
\text { environmental impact }\end{array} & \text { and }\end{array}$ & $\mathrm{x}$ & $x$ & $\mathrm{x}$ & $\mathrm{B} 2 \mathrm{~B}$ and $\mathrm{B} 2 \mathrm{C}$ \\
\hline Perceived quality & & $\mathrm{x}$ & $x$ & $\mathrm{~B} 2 \mathrm{~B}$ and $\mathrm{B} 2 \mathrm{C}$ \\
\hline Aesthetics & $\mathrm{x}$ & $x$ & $\mathrm{x}$ & $\mathrm{B} 2 \mathrm{~B}$ and $\mathrm{B} 2 \mathrm{C}$ \\
\hline
\end{tabular}

Source: Elaborated by the author authors

The features characteristic refers to the complementary features provided in addition to the basic functioning of the tangible goods. They add value to the tangible goods but are not explicit user requirements. Falling short of this requirement may cause customers to not consume the PSS or to complain. For product- and resultoriented PSSs, customers consider features to enable use: features increase the convenience, ease, and safety of operation.

Four requirements relate to the time of use of tangible goods: reliability, availability, maintainability, and durability. Reliability refers to the faultless operation of the tangible goods within a specified period. Availability is the guarantee that the tangible goods will be available for use when needed. Maintainability corresponds to preventive and corrective maintenance of the tangible goods. Durability refers to the lifetime of the technical characteristics of the tangible goods. Durability relates to the use of tangible goods before their deterioration, when replacement is preferable to repair. For product-oriented-PSS customers, use of tangible goods should not easily lead to damage. Result-oriented-PSS customers point out that durability is a guarantee of the outcome.

Compliance refers to the degree to which design and operation of tangible goods agree with customer specifications. In addition, use-oriented-PSS customers associate compliance to the safety of tangible goods during use. For product and result-oriented-PSS customers, compliance refers to whether the tangible goods comply with safety standards. Therefore, compliance is related to all characteristics involved with customer security. 
Environmental impact and sustainability refers to the impact of the tangible goods on the environment and society in general. Perceived quality refers to the criteria that give the customer the perception that their needs are satisfied by using the tangible goods. Customers stress the importance of using trademarks recognized by the market. The use of recognized brands can mitigate customer uncertainty regarding PSS performance.

Aesthetics refers to aspects of the physical appearance of tangible goods and reflects individual-customer preferences. For use-oriented-PSS customers, tangible goods must be clean and in good condition. Result-oriented-PSS customers interact directly with the infrastructure to obtain the PSS result (e.g., consulting). In this case, they assess the cleanliness of facilities. For product-oriented-PSS customers, aesthetics includes the design of tangible goods, because it influences how the goods perform their main function.

\subsection{Requirements associated with service dimension}

Requirements associated with the service dimension are named as per the dimensions of the model developed by Parasuraman et al. (1991). This model encompasses SERVQUAL, which contains 44 questions, of which 22 relate to customer expectations and 22 assess customer perception of quality of service. These issues are divided into five dimensions: reliability, responsiveness, security, empathy, and tangible. In addition, the support requirement is included in the service dimension.

Integrate product and service can be regarded as one of the dimensions for improving service quality and customer satisfaction (SUH; JEON, 2015). Table 3 presents the six customer requirements related to the service dimension.

Table 3: Service requirements.

\begin{tabular}{|l|l|l|l|l|}
\hline Requirement & $\begin{array}{l}\text { Product- } \\
\text { oriented } \\
\text { product- } \\
\text { servicesy } \\
\text { stem }\end{array}$ & $\begin{array}{l}\text { Use-oriented } \\
\text { product- } \\
\text { servicesyste } \\
\mathbf{m}\end{array}$ & $\begin{array}{l}\text { Result- } \\
\text { oriented } \\
\text { product- } \\
\text { servicesyste } \\
\mathbf{m}\end{array}$ & $\begin{array}{l}\text { Type } \\
\text { transaction }\end{array}$ \\
\hline Tangible & & $\mathrm{X}$ & $\mathrm{X}$ & $\mathrm{B}$ of \\
\hline Service Reliability & $\mathrm{X}$ & $\mathrm{X}$ & $\mathrm{X}$ & $\mathrm{B} 2 \mathrm{~B}$ and B2C \\
\hline Empathy & $\mathrm{X}$ & $\mathrm{X}$ & $\mathrm{X}$ & $\mathrm{B}$ B B and B2C \\
\hline Responsiveness & $\mathrm{X}$ & $\mathrm{X}$ & $\mathrm{X}$ & $\mathrm{B} 2 \mathrm{~B}$ and B2C \\
\hline Security & $\mathrm{X}$ & $\mathrm{X}$ & $\mathrm{X}$ & $\mathrm{B} 2 \mathrm{~B}$ and B2C \\
\hline Support & $\mathrm{X}$ & $\mathrm{X}$ & $\mathrm{X}$ & $\mathrm{B} 2 \mathrm{~B}$ and B2C \\
\hline
\end{tabular}


Tangibility consists of tangible aspects that help to provide the service, such as equipment, facilities, or communication material (LEE et al., 2015; KIMITA et al. 2009). Use-oriented-PSS customers cite the way in which the employees of PSS providers dress. Result-oriented-PSS customers highlight the example of the material produced by the PSS provider for meetings.

Service reliability is the extent to which all agreements made between provider and customer are accomplished (SHENG et al., 2015; KIM et al., 2015). This dimension helps gain customer confidence. Empathy is the degree of care and personal attention afforded customers by the PSS provider (MERT et al., 2014; SHIMOMURA et al., 2013). Empathy enables a closer relationship between provider and customer, which leads to greater satisfaction. It refers to dynamic relational PSS providers.

Responsiveness involves the arrangements made by the PSS provider to assist their customers and how ready the provider is to meet customer needs as and when required (CATULLI, 2012; KIM; YOON, 2012). Responsiveness also refers to the provider's availability outside normal working hours and their response time.

Support refers to all assistance from PSS providers that ensures that, once the PSS is acquired, it functions properly (SAKAO; LINDAHL, 2012; AN et al., 2008). For product-oriented-PSS customers, this requirement applies both to after-sales technical support and to the extension of the support during PSS use. For these customers, support should be technical and managerial. For result-oriented-PSS customers, the type of support provided by the PSS provider should be determined when the PSS is acquired. At least, the requirement security refers to the knowledge of employees and their skills that inspire customer confidence (REXFELT; HIORT AF ORNÄS, 2009).

\subsection{Requirements associated with general aspects of product-service system}

The general PSS dimension contains requirements for provider, tangible goods, and services but do not relate to the dimensions of Garvin (1984) and Parasuraman et al. (1991). Altogether, 21 requirements are grouped into this dimension, as shown in Table 4. 
INDEPENDENT JOURNAL OF MANAGEMENT \& PRODUCTION (IJM\&P)

http://www.ijmp.jor.br

v. 9, n. 2, April - June 2018

ISSN: 2236-269X

DOI: 10.14807/ijmp.v9i2.688

Table 4: General PSS requirements.

\begin{tabular}{|c|c|c|c|c|}
\hline Requirement & \begin{tabular}{|l|} 
Product- \\
oriented \\
product- \\
servicesyst \\
em \\
\end{tabular} & \begin{tabular}{|l|} 
Use- \\
oriented \\
product- \\
servicesy \\
stem
\end{tabular} & $\begin{array}{l}\text { Result- } \\
\text { oriented } \\
\text { product- } \\
\text { servicesyst } \\
\text { em }\end{array}$ & $\begin{array}{l}\text { Type of } \\
\text { transaction }\end{array}$ \\
\hline Good update & $\mathrm{x}$ & $\mathrm{x}$ & & B2B \\
\hline Convenience & & $\mathrm{x}$ & $\mathrm{x}$ & $\begin{array}{l}\text { B2B } \\
\text { B2C }\end{array}$ \\
\hline Communication & $\mathrm{x}$ & $x$ & $\mathrm{x}$ & $\begin{array}{l}\text { B2B } \\
\text { B2C }\end{array}$ \\
\hline Knowledge & $x$ & & $x$ & $\begin{array}{l}\text { B2B } \\
\text { B2C }\end{array}$ \\
\hline Contract & $\mathrm{x}$ & $x$ & $x$ & B2B \\
\hline $\begin{array}{ll}\begin{array}{l}\text { Product-service } \\
\text { conformance }\end{array} & \text { system } \\
\end{array}$ & & & $\mathrm{x}$ & B2C \\
\hline Legal and regulatory compliance & & $x$ & $\mathrm{x}$ & $\begin{array}{l}\text { B2B } \\
\text { B2C }\end{array}$ \\
\hline Cost & $x$ & $x$ & $x$ & $\begin{array}{l}\text { B2B } \\
\text { B2C }\end{array}$ \\
\hline Customizing & $x$ & $x$ & $\mathrm{x}$ & $\begin{array}{l}\text { B2B } \\
\text { B2C }\end{array}$ \\
\hline Stability & & $x$ & $x$ & $\begin{array}{l}\text { B2B } \\
\text { B2C }\end{array}$ \\
\hline Warranty & & $x$ & $\mathrm{x}$ & $\begin{array}{l}\mathrm{B} 2 \mathrm{~B} \\
\mathrm{~B} 2 \mathrm{C}\end{array}$ \\
\hline $\begin{array}{l}\text { Outsourcing } \\
\text { system provider }\end{array}$ & & & $\mathrm{x}$ & B2B \\
\hline $\begin{array}{l}\text { Product-service system provider } \\
\text { location }\end{array}$ & $\mathrm{x}$ & & $\mathrm{x}$ & $\begin{array}{l}\text { B2B } \\
\text { B2C }\end{array}$ \\
\hline Proactivity & & & $\mathrm{x}$ & B2B \\
\hline Property of goods & & $\mathrm{x}$ & & B2B \\
\hline Long-term relationship & & $\mathrm{x}$ & & B2B \\
\hline Perceived quality & & $x$ & & B2B \\
\hline $\begin{array}{l}\text { Customer and provider } \\
\text { responsibilities }\end{array}$ & & $x$ & $\mathrm{x}$ & B2B \\
\hline Goods replacement & & $\mathrm{x}$ & & B2B \\
\hline Tradeoff & & $\mathrm{x}$ & & B2B \\
\hline Product-service system variety & $x$ & $x$ & $x$ & $\begin{array}{l}\text { B2B } \\
\text { B2C }\end{array}$ \\
\hline
\end{tabular}

Source: Elaborated by the author authors

Tangible goods update refers to the possibility of replacing the goods with an updated version when necessary (SHENG et al., 2015; GENG; CHU, 2012). Product- and use-oriented-PSS customers are willing to pay for the tangible goods upgrade provided the price is agreed upon when the PSS is acquired. Convenience relates to the characteristics that supplement the basic PSS operations to facilitate the purchase, use, and disposal thereof (LEE et al., 2015; MAZO; BORSATO, 2014). Communication includes all information-transfer processes between provider and customer (SHIH; CHOU, 2011; GENG et al., 2011).

Knowledge refers to the skills and technical knowledge offered by the PSS provider (TU et al. 2013; KIM; YOON, 2012). For product- and result-oriented-PSS 
INDEPENDENT JOURNAL OF MANAGEMENT \& PRODUCTION (IJM\&P)

http://www.ijmp.jor.br

v. 9, n. 2, April - June 2018

ISSN: 2236-269X

DOI: 10.14807/ijmp.v9i2.688

customers, employees involved in providing the PSS must have technical qualifications attested to by certificates and experience. Knowledge of business and industry on the part of the PSS provider is an important requirement for resultoriented-PSS customers.

Contract refers to the agreement made between provider and customer when the PSS is purchased (TU et al., 2013). In this way, both parties are obliged to comply with certain conditions within the legal framework of the locality. Long-term contracts allow economies of scale (KUO, 2013). Customers point out that the contract is a means to ensure the availability of the PSS. The nature and form of the contract influences customer satisfaction and the consumption decision.

PSS conformance refers to compliance by the provider with service-level agreements (SAKAO; LINDAHL, 2012; KIMITA et al. 2009). It refers to the degree to which customer expectations are met by the PSS provider. Legal and regulatory compliance relates to the compliance by the PSS provider with all relevant rules and regulations (MAZO; BORSATO, 2014; KIM; YOON, 2012). Generally, government enforces these rules and regulations. Use-oriented-PSS customers state that the provider must demonstrate the knowledge and ability to meet the standards and regulations that govern the given PSS sector and customer business.

Cost refers to the monetary amount spent by the customer at the time of purchase, use, and disposal of the PSS and includes the price charged by the PSS provider (RAJA et al., 2013; GENG et al., 2010). Customers appear to be sensitive to the existence of recurrent costs that accumulate during the lifetime of the PSS. As claimed by customers, the cost of the PSS should be less than the sum of the cost of its components.

Customizing refers to personalization and adapting the PSS to customer needs (GENG et al., 2010; KANG et al., 2014). For product-oriented-PSS customers, the PSS needs to be less static and standardized, which contradicts some studies on PSS modularization [see, e.g., Li et al. (2015)]. They also highlight the capacity of PSSs to evolve with use. For use- and result-oriented-PSS customers, customization should be possible both at purchase and during PSS use. Stability refers to the constancy of PSS performance during use. 
INDEPENDENT JOURNAL OF MANAGEMENT \& PRODUCTION (IJM\&P)

http://www.ijmp.jor.br

v. 9, n. 2, April - June 2018

ISSN: 2236-269X

DOI: 10.14807/ijmp.v9i2.688

Warranty refers to the period during which the PSS provider will fix problems and defects at no charge to the customer (TU et al., 2013; CATULLI, 2012). Outsourcing PSS provider refers to the ability of the PSS provider to hire another company to meet new customer needs (SHIMOMURA et al., 2013; TOOSSI et al., 2013). This is an important requirement when occurs a customer's business change. PSS provider location refers to the distance from the provider to where the PSS is used (RAJA et al., 2013; SAKAO et al., 2009). Customers highlight how provider location affects the provider's ability to maintain tangible goods. Proactivity relates to the ability of the PSS provider to predict unfavorable situations and act before errors occur (SHIMOMURA et al., 2013). Result-oriented-PSS customers state that this requirement favors continuous PSS improvement and a sense of urgency in solving problems.

Property of tangible goods relates to the need for possession of the tangible goods by the PSS customer (SHIH; CHOU, 2011; REXFELT; HIORT AF ORNÄS, 2009). Long-term relationship refers to the establishment of obligations over the long-term use of the PSS (CATULLI, 2012). This requirement is cited mainly for B2B customers. Use-oriented-PSS customers do not consider the long-term relationship to be a decisive factor for their consumption. On the contrary, these customers prefer to not consume the PSS if a long-term relationship is required. In this case, the use of tangible goods for a short period foments PSS consumption.

Perceived quality addresses customer expectations regarding the PSS, these expectations are built from the experience of other customers and by the marketing provider (KIM et al., 2015, TU et al., 2013). This requirement refers to the reputation and image of the PSS provider in the market.

Customer and provider responsibilities refers to the clear and precise definition of the responsibilities between the two parties during PSS use (MAZO; BORSATO, 2014). These responsibilities are defined when the PSS is acquired. The contract is the official means of establishing responsibilities. It is noticed that a lower responsibility translates into a higher likelihood of PSS consumption.

Tangible goods replacement refers to the possibility of the replacement of the tangible goods being guaranteed by the PSS provider in the event of damage, failure, and/or misuse by the customer (Lee et al., 2015). Trade-off refers to the 
INDEPENDENT JOURNAL OF MANAGEMENT \& PRODUCTION (IJM\&P)

http://www.ijmp.jor.br

v. 9, n. 2, April - June 2018

ISSN: 2236-269X

DOI: 10.14807/ijmp.v9i2.688

benefits from isolated acquisition components of the PSS (tangible goods or services) or to the purchase the PSS itself (SAKAO; LINDAHL, 2012).

Finally, PSS variety refers to the assortment of tangible goods and services associated with the PSS (AN et al., 2008). Moreover, this requirement includes the possibility of different combinations between tangible goods and services. The PSS provider should, in cooperation with the customer, define the most appropriate service to be associated with the tangible goods at the time of acquisition. This approach increases the added value provided by the PSS.

\section{CONCLUSIONS}

After analyzing the results, we confirm that few empirical studies investigate PSS-customer requirements. Only about $10 \%$ of the studies identified in this systematic literature review focusing on PSSs discuss customer requirements. Thirty-seven customer requirements are identified and are grouped based on three criteria: (i) type of PSS, (ii) type of transaction, and (iii) PSS dimension. Empirical studies tend to focus on identifying customer requirements for use- and resultoriented PSSs. Regarding the type of transaction, $70 \%$ of the identified articles focus on the B2B context, which is consistent with the statement of Schenkl et al. (2014) that empirical studies in the B2C context are scarce. Therefore, more research should be directed to B2C customers.

The requirements are divided as follows: nine requirements make up the tangible goods dimension related to the PSS product. The service dimension contains six requirements that relates to the PSS service component. Finally, the general PSS dimension has 22 requirements, which include several PSS items reported by customers.

The focus of $65 \%$ of the selected articles is to incorporate customer requirements into the PSS development process by using one of two approaches: by focusing on the conceptual design or by including the customer requirements at some stage of the development process. The other articles from the sample focus on PSS customers from three viewpoints: (i) identify the customer requirements that affect the PSS customer decision, (ii) assess the PSS quality, and (iii) identify the group requirements of specific customers. 
Thus, this study suggests that the goal of empirical studies was to identify customer requirements. In addition, we recommend validating the customer requirements presented here in relation to the sector for which the PSS is intended. In addition, we recommend using empirical data to check if regional differences exist in customer requirements.

\section{REFERENCES}

AN, Y.; LEE, S.; PARK, Y. (2008). Development of an integrated product-service roadmap with QFD. International Journal of Service Industry Management, v. 19, n. 5, p. 621-638.

CARREIRA, R.; PATRÍCIO, L.; JORGE, R. N.; MAGEE, C. L. (2013). Development of an extended Kansei engineering method to incorporate experience requirements in product-service system design. Journal of Engineering Design, v. 24, n. 10, p. 738-764.

CASSIA, F.; UGOLINI, M. M.; COBELLI, N.; GILL, L. (2015). Service-based vs. goods-based positioning of the product concept. TQM Journal, v. 27, n. 2, p. 247255.

CATULLI, M. (2012). What uncertainty? Journal of Manufacturing Technology Management, v. 23, n. 6, p. 780-793.

CHATHA, K. A.; BUTT, I.; TARIQ, A. (2015). Research methodologies and publication trends in manufacturing strategy. International Journal of Operations and Production Management, v. 35, n. 4, p. 487-546.

CHOU, C.-J.; CHEN, C.-W.; CONLEY, C. (2015). An approach to assessing sustainable product-service systems. Journal of Cleaner Production, n. 86, p. 277-284.

COOK, M. (2004). Understanding the potential opportunities provided by service orientated concepts to improve resource productivity. In: Bhamra, Tracy and Hon, Bernard eds. Design and Manufacture for Sustainable Development. Wiley, New York.

CRESWELL, J. W. (1994). Research Design: Qualitative and Quantitative Approaches. Thousand Oaks, CA: Sage Publications.

DANGAYACH, G. S.; DESHMUKH, S. G. (2001). Manufacturing strategy: Literature review and some issues. International Journal of Operations \& Production Management, v. 21, n. 7, p. 884-932.

DUMAY, J.; GUTHRIE, J.; PUNTILLO, P. (2015). IC and public sector: a structured literature review. Journal of Intellectual Capital, v. 16, n. 2, p. 267-284.

ELORANTA, V.; TURUNEN, T. (2015). Seeking competitive advantage with service infusion: A systematic literature review. Journal of Service Management, v. 26, n. 3, p. 394-425.

GARFIELD, E. (1972). Citation analysis as a tool in journal evaluation. Science, v. 178, n. 4060, p. 471-479. 
INDEPENDENT JOURNAL OF MANAGEMENT \& PRODUCTION (IJM\&P)

http://www.ijmp.jor.br

v. 9, n. 2, April - June 2018

ISSN: 2236-269X

DOI: 10.14807/ijmp.v9i2.688

GARVIN, D. A. (1984). What Does Product Quality Really Mean. Sloan Management Review, Fall, 25-43.

GENG, X.; CHU, X. (2012). A new importance-performance analysis approach for customer satisfaction evaluation supporting PSS design. Expert Systems with Applications, v. 39, n. 1, p. 1492-1502.

GENG, X.; CHU, X.; XUE, D.; ZHANG, Z. (2011). A systematic decision-making approach for the optimal product-service system planning. Expert Systems with Applications, n. 38, p. 11849-11858.

GENG, X.; CHU, X.; XUE, D.; ZHANG, Z. (2010). An integrated approach for rating engineering characteristics' final importance in product-service system development. Computers \& Industrial Engineering, n. 59, p. 585-594.

GENG, X.; CHU, X.; ZHANG, Z. (2012). An association rule mining and maintaining approach in dynamic database for aiding product-service system conceptual design. International Journal of Advanced Manufacturing Technology, n. 62, p. 1-13.

GOEDKOOP, M.; VAN HALEN, C.; TE RIELE, H.; ROMMENS, P. (1999). Product Service-Systems, ecological and economic basics. Report for Dutch Ministries of Environment (VROM) and Economic Affairs (EZ). Retrieved March 27, 2016, from http://teclim.ufba.br/jsf/indicadores/holan\%20Product\%20Service\%20Systems\%20m ain\%20report.pdf

HARWOOD, T. G.; GARRY, T. (2003). An overview of content analysis. The Marketing Review, v. 3, n. 4, p. 479-498.

KANG, Y.; LEE, M.; LEE, S. (2014). Service-oriented factors affecting the adoption of Smartphones. Journal of Technology Management \& Innovation, v. 9, n. 2, p. 98-117.

KIM, S.; YOON, B. (2012). Developing a process of concept generation for new product-service systems: a QFD and TRIZ-based approach. Service Business, n. 6, p. 323-348.

KIM, S.; SON, C.; YOON, B.; PARK, Y. (2015). Development of an innovation model based on a service-oriented product service system (PSS). Sustainability

(Switzerland), v. 7, n. 11, p. 14427-14449.

KIMITA, K.; SHIMOMURA, K.; ARAI, T. (2009). Evaluation of customer satisfaction for PSS design. Journal of Manufacturing Technology Management, v. 20, n. 5, p. 654-673.

KUO, T.C. (2013). Mass customization and personalization software development: a case study eco-design product service system. Journal of Intelligent Manufacturing, n. 24, p. 1019-1031.

LEE, S.; GEUM, Y.; LEE, S.; PARK, Y. (2015). Evaluating new concepts of PSS based on the customer value: Application of ANP and niche theory. Expert Systems with Applications, v. 42, n. 9, p. 4556-4566.

LIPKIN, M. (2016) Customer experience formation in today's service landscape. Journal of Service Management, v. 27, n. 5, p. 678-703.

MAZO, S. Z.; BORSATO, M. (2014). An enhanced tool for incorporating the voice of the customer in product-service systems. International Journal of Mechanical

Engineering and Automation, v. 1, n. 2, p. 57-76. 
INDEPENDENT JOURNAL OF MANAGEMENT \& PRODUCTION (IJM\&P)

http://www.ijmp.jor.br

v. 9, n. 2, April - June 2018

ISSN: 2236-269X

DOI: 10.14807/ijmp.v9i2.688

MERT, G.; WALTEMODE, S.; AURICH, J. C. (2014). Quality assessment of technical product-service systems in the machine tool industry. Procedia CIRP, $\mathrm{n}$. 16, p. 253-258.

MIAN, P.; CONTE, T.; NATALI, A.; BIOLCHINI, J.; TRAVASSOS, G. (2005) A Systematic Review Process for Software Engineering. Retrieved March 27, 2016, from http://www.lbd.dcc.ufmg.br/colecoes/eselaw/2005/009.pdf

MINOR, E. D.; HENSLEY, R. L.; WOOD JR., R. D. (1994). A review of empirical manufacturing strategy studies. International Journal of Operations and Production Management, v. 14, n. 1, p. 5-25.

MONT, O. (2001). Introducing and Developing a PSS in Sweden. Retrieved March 27, 2016, from https://lup.lub.lu.se/search/publication/525784

OLIVA, R.; KALLENBERG, R. (2003). Managing the transition from products to services. International Journal of Service Industry Management, v. 14, n. 2, p. 160-172.

PAN, J.-N.; NGUYEN, H. T. N. (2015). Achieving customer satisfaction through product-service systems. European Journal of Operational Research, v. 247, n. 1, p. 179-190.

PARASURAMAN, A.; ZEITHAML, V. A.; BERRY, L. L. (1991). Refinement and reassessment of the SERVQUAL scale. Journal of Retailing, v. 67, n. 4, p. 420-50.

PLEWIS, I.; MASON, P. (2005). What works and why: Combining quantitative and qualitative approaches in large-scale evaluations. International Journal of Social Research Methodology, v. 8, n. 3, p. 185-194.

RAJA, J. Z.; BOURNE, D.; GOFFIN, K.; ÇAKKOL, M.; MARTINEZ, V. (2013). Achieving customer satisfaction through integrated products and services: An exploratory study. Journal of Product Innovation Management, v. 30, n. 6, p. 1128-1144.

REIM, W.; PAIRDA, V.; ÖRTQVIST, D. (2015). Product-Service Systems (PSS) business models and tactics - A systematic literature review. Journal of Cleaner Production, n. 97, p. 61-75.

REXFELT, O.; HIORT AF ORNÄS, V. (2009). Customer acceptance of productservice systems: Designing for relative advantages and uncertainty reductions. Journal of Manufacturing Technology Management, v. 20, n. 5, p. 674-699.

SAKAO, T.; LINDAHL, M. (2015). A method to improve integrated product service offerings based on life cycle costing. CIRP Annals - Manufacturing Technology, v. 64, n. 1, p. 33-36.

SAKAO, T.; LINDAHL, M. (2012). A value based evaluation method for Product/Service System using design information. CIRP Annals - Manufacturing Technology, v. 61, n. 1, p. 51-54.

SCHENKL, S. A.; RÖSCH, C.; MÖRTL, M. (2014). Literature study on factors influencing the market acceptance of PSS. Procedia CIRP, n. 16, p. 98-103.

SEURING, S.; MULLER, M. (2008). From a literature review to a conceptual framework for sustainable supply chain management. Journal of Cleaner Production, n. 16, p. 1699-1710. 
SHENG, Z.; LU, F.; WU, L. (2015). Domain Mapping of Product Service System Oriented on CNC Machine Tools. Control engineering and applied informatics, v. 17, n. 4, p. 59-70.

SHIH, L. H.; CHOU, T. Y. (2011). Customer concerns about uncertainty and willingness to pay in leasing solar power systems. International Journal of Environmental Science and Technology, v. 8, n. 3, p. 523-532.

SHIMONURA, Y.; KIMITA, K.; TATEYAMA, T.; AKASAKA, F.; NEMOTO, Y. (2013). A method for human resource evaluation to realize high-quality PSSs. CIRP Annals - Manufacturing Technology, v. 62, n. 1, p. 471-474.

SUH, Y.; JEON, J. (2015). Do integrated products and services increase customer satisfaction? The case of the mobile industry in Korea. Total Quality Management \& Business Excellence, v. 11-12, n. 27, p. 1261-1276

TOOSSI, A.; LOCKETT, H. L.; RAJA, J. Z.; MARTINEZ, V. (2013). Assessing the value dimensions of outsourced maintenance services. Journal of Quality in Maintenance Engineering, v. 19, n. 4, p. 348-363.

TRANFIELD, D.; DENYER, D.; SMART, P. (2003). Towards a Methodology for Developing Evidence-Informed Management Knowledge by Means of Systematic Review. British Journal of Management, n. 14, p. 207-222.

TU, J.-C.; HUANG, Y.-C.; HSU, C.-Y.; CHENG, Y.-W. (2013). Analyzing lifestyle and consumption pattern of hire groups under product service systems in Taiwan. Mathematical Problems in Engineering, 2013, 15.

VEZZOLI, C.; CESCHIN, F.; DIEHL, J. C.; KOHTALA, C. (2015). New design challenges to widely implement 'Sustainable Product-Service Systems'. Journal of Cleaner Production, n. 97, p. 1-12.

YOON, B.; KIM, S.; RHEE, J. (2012). An evaluation method for designing a new product-service system. Service Business, v. 6, n. 3, p. 323-348.

ZHENG, M.; MING, X.; LI, M.; HE, L. (2015). A framework for Industrial ProductService Systems risk management. Journal of Risk and Reliability, v. 229, n. 6, p. 501-516. 